\title{
ANALYSIS OF LEARN DISCIPLINE IN IMPLANTATION CHARACTER EDUCATION OF IVA STUDENTS AT SD NEGERI 5 PANJER IN 2018
}

\author{
Universitas Sebelas Maret \\ rismamila23@gmail.com
}

Rokhmaniyah, Risma Mila Ardila

\begin{tabular}{l} 
Article History \\
\hline accepted 30/09/2018 \\
approved 12/10/2018 \\
published 30/10/2018
\end{tabular}

Keywords

learn discipline, character

\begin{abstract}
This article describes the results of the study which aims to: (1) analyze the learning discipline of IVa students of SD Negeri 5 Panjer in 2018; (2) describes the teacher's efforts in overcoming students' indiscipline of learning. This research approach is qualitative by descriptive method. Data collection techniques used are observation, interviews, and documentation. The subjects of this study were students of grade IVa SD N 5 Panjer. Data sources of this study are students, teachers, and principals. To maintain the validity of the research data techniques and source triangulation were used. The results showed that the indiscipline of IVa class students included arriving late, not paying attention to the teacher's explanation, entering-leaving the classroom without permission, not collecting tasks on time, not carrying school tools, and skipping school. The efforts made by the teacher overcoming the above include understanding the characteristics of students and give a warning and advice.
\end{abstract}

$\begin{array}{ll}\text { Social, Humanities, and Education Studies (SHEs): Conference Series } & \text { p-ISSN 2620-9284 } \\ \text { https://jurnal.uns.ac.id/shes } & \text { e-ISSN 2620-9292 }\end{array}$




\section{PENDAHULUAN}

Pendidikan karakter mulai diberlakukan sejak tahun 2010 dan terus berlaku hingga sekarang. Dalam pendidikan karakter terdapat beberapa nilai, salah satunya adalah disiplin. Harlock (1999) menyebutkan tujuan kedisiplinan untuk membentuk perilaku yang sesuai dengan peran yang telah ditetapkan oleh suatu kelompok (Anggraini, 2014). Dengan demikian, karakter disiplin penting karena tanpa disiplin anak pada umumnya tidak akan bertahan dalam suatu kelompok sebab aturan menjadi pegangan dalam kehidupan bagi suatu kelompok. Mengapa? Karena manusia adalah makhluk sosial yang tidak bisa hidup tanpa orang lain. Dengan demikian, disiplin harus diterapkan di semua lingkungan, termasuk lingkungan sekolah. Sekolah merupakan rumah kedua bagi siswa untuk menuntut ilmu setelah lingkungan keluarga. Pada umumnya sekolah termasuk dalam kategori lingkungan yang memiliki kedisiplinan tinggi. Kedisiplinan akan menghasilkan watak dan kepribadian yang baik yang sesuai dengan tujuan pendidikan nasional yang dijelaskan dalam Undang-Undang RI No. 23 tahun 2003 tentang Sistem Pendidikan Nasional Bab 2 Pasal 3 yang berbunyi :

"Pendidikan Nasional berfungsi mengembangkan kemampuan dan membentuk watak serta peradaban bangsa yang bermartabat dalam rangka mencerdaskan kehidupan bangsa, bertujuan untuk berkembangnya potensi peserta didik agar menjadi manusia yang beriman dan bertakwa kepada Tuhan Yang Maha Esa, berakhlak mulia, sehat, berilmu, cakap, kreatif, mandiri, dan menjadi warga negara yang demokratis serta bertanggung jawab".

Kedisiplinan terdapat dalam segala aspek kehidupan, termasuk kedisiplinan belajar. Suyono dan Hariyanto (2014: 9) menyatakan bahwa belajar ialah suatu aktivitas atau proses untuk memperoleh pengetahuan, meningkatkan keterampilan, memperbaiki sikap, dan mengokohkan kepribadian. Salah satu tujuan belajar adalah memperbaiki sikap dan kepribadian. Untuk memperbaikinya diperlukan kedisiplinan yakni kedisiplinan belajar siswa. Kedisiplinan belajar siswa di dalam kelas terjadi saat siswa mampu menempatkan dirinya pada kegiatan belajar-mengajar. Apabila terdapat kedisiplinan belajar pada diri siswa maka guru dapat mengontrol perilaku siswa agar tercapai kelas yang kondusif dan nyaman guna tercapainya tujuan pembelajaran. Apabila tidak ada kedisiplinan belajar maka kelas tidak akan kondusif dan nyaman akibatnya tujuan pembelajaranpun tidak akan tercapai dengan maksimal. Oleh karena itu, karakter disiplin terutama dalam pembelajaran menjadi hal yang penting dalam menciptakan perilaku siswa yang tertib aturan.

Berdasarkan data yang diperoleh dari guru kelas di kelas IVa dan kepala sekolah SD Negeri 5 Panjer dan diperkuat dengan hasil observasi pada saat proses pembelajaran, menunjukkan sebagian siswa belum memiliki disiplin belajar yang baik. Hal ini terbukti ditemukan permasalahan mengenai kedisiplinan. Permasalahan tersebut adalah: 1) siswa datang terlambat baik saat awal masuk pada pagi hari atau setelah waktu istirahat; 2) tidak memperhatikan saat guru memberikan penjelasan; 3) membuat gaduh; 4) keluar masuk ruang kelas tanpa izin guru; 5) berbicara dengan temannya; 6) sibuk dengan kegiatannya masingmasing; 7) tidak mengumpulkan tugas tepat waktu; 8) tidak membawa buku atau alat sekolah; 9) menganggu temannya saat pembelajaran; 10) membolos. Selain permasalahan di atas, di kelas IVa terdapat satu siswa, yaitu Ro yang mempunyai banyak catatan kasus oleh guru kelasnya. Ro adalah salah satu siswa yang kurang memiliki kedisiplinan dalam belajar sehingga anak tersebut membutuhkan perhatian lebih dalam pembelajaran. Guru kelas IV A menambahkan, bahwa beberapa kekurangan kedisiplinan dari sebagian anak adalah karena masih ada pengaruh dari kebiasaan di kelas rendah, baik mengenai materi dan isi pembelajaran serta kebiasaan belajar mereka. Padahal, guna mencapai tujuan pembelajaran salah satu karakter yakni kedisiplinan belajar siswa harus benar-benar dipahami.

Alternatif dari permasalahan kedisiplinan belajar siswa di atas salah satunya pendekatan dari guru. Guru sebagai pengajar dan pendidik harus memahami karakteristik siswa. Seorang anak tidak dapat dipaksakan untuk melakukan hal secara spontanitas. Oleh karena itu, alternatif dan upaya dari guru kelas terus dilakukan antara lain pendekatan dengan siswa, tidak menggunakan kekerasan, memberikan bimbingan dan peringatan, serta prinsip fleksibilitas guru agar siswa merasa nyaman dan aman selama di kelas.

Dari permasalahan yang telah di uraian di atas, mpeneliti sebagai seorang akademisi yang peduli terhadap perkembangan pendidikan anak-anak, mencoba untuk membahas 
penelitian ini. Permasalahan yang akan dianalisis antara lain: (1) bagaimanakah kedisiplinan belajar dalam penanaman pendidikan karakter siswa kelas IVa SD Negeri 5 Panjer Tahun 2018?; (2) bagaimanakah upaya guru dalam mengatasi ketidakdisiplinan belajar dalam penanaman pendidikan karakter siswa kelas IVa SD Negeri 5 Panjer Tahun 2018?. Penelitian di atas dideskripsikan dalam penelitian yang berjudul "Analisis Kedisiplinan Belajar dalam Penanaman Pendidikan Karakter Siswa Kelas IVa SD Negeri 5 Panjer Tahun 2018."

\section{METODE}

Penelitian ini menggunakan penelitian kualitatif metode deskriptif, artinya data yang dikumpulkan bukanlah angka-angka namun data deskriptif yang berasal dari wawancara, observasi, serta dokumentasi. Wawancara yang dilakukan oleh peneliti menggunakan wawancara langsung terstruktur kepada guru kelas IVa menggunakan pedoman wawancara dan wawancara tidak terstruktur kepada kepala sekolah SD Negeri 5 Panjer sehingga peneliti dapat memperoleh hasil yang diinginkan. Kedua, peneliti mengumpulkan data dengan observasi menggunakan lembar observasi yaitu mengamati langsung objek penelitian yaitu kedisiplinan belajar siswa di kelas IVa SD Negeri 5 Panjer. Dan terakhir menggunakan dokumentasi dengan melihat catatan-catatan lain dari guru serta dokumentasi berupa foto-foto saat observasi pembelajaran. Menurut N.K Malhotra (2006), "tahap analisis data dalam penelitian kualitatif secara umum dimulai sejak analisis data, reduksi data, penyajian data, dan penarikan kesimpulan atau verifikasi" (Sangadji dan Sopiah, 2010: 199). Dalam penelitian kualitatif deskriptif ini peneliti melakukan pengumpulan data terlebih dahulu melalui teknik yang telah disebutkan. Selanjutnya, data direduksi dan dipilah sehingga terdapat gambaran pokok penelitian. Setelah itu, data disajikan dan ditarik atau diambil kesimpulan penelitiannya. Tujuan penelitian ini tentunya untuk menggambarkan, mengungkapkan, dan menyajikan apa adanya tentang kedisiplinan belajar dalam penanaman pendidikan karakter siswa di kelas IVa SD Negeri 5 Panjer Tahun 2018.

\section{HASIL DAN PEMBAHASAN \\ 1. Kedisiplinan Belajar dalam Penanaman Pendidikan Karakter Siswa Kelas IVa SD Negeri 5 Panjer}

Disiplin merupakan salah satu nilai diantara 18 nilai pendidikan karakter yang sedang digalakkan oleh pemerintah, maka keberadaanya dapat dikatakan sangat penting. Maman Rachman (1997) menyebutkan kedisiplinan sebagai pernyataan sikap mental dari seseorang maupun masyarat yang mencerminkan rasa ketaatan, dan kepatuhan yang didukung oleh kesadaran diri untuk melaksanakan tugas dan kewajiban yang diberikan (Anggraini, 2014). Selain itu, Sciara (2010), mendefinisikan disiplin sebagai "the measures taken in order to establish, maintain or restore order and combat or modify disruptive behavior." yang intinya bahwa disiplin adalah tindakan yang diambil untuk menetapkan, memelihara atau memulihkan ketertiban dan memerangi atau memodifikasi perilaku mengganggu. Unaradja (2003) menyebutkan terbentuknya kedisiplinan sebagai tingkah laku dipengaruhi oleh 2 faktor, yaitu: 1) faktor internal, yaitu faktor yang berasal dari dalam diri siswa, baik itu keadaan fisik yang dapat melaksanakan tugas dan keadaan psikis yang dapat menghayati norma yang ada di keluarga ataupun di masyarakat (Anggraini, 2014). Suyono dan Hariyanto (2014: 9) menyatakan bahwa belajar ialah suatu aktivitas atau proses untuk memperoleh pengetahuan, meningkatkan keterampilan, memperbaiki sikap, dan mengokohkan kepribadian.

Berdasarkan uraian di atas, kedisiplinan belajar adalah sikap seseorang atau kelompok yang taat, tertib, dan teratur dalam melaksanakan tugas dan kewajibannya atas kesadaran dirinya dalam proses belajar mengajar di dalam suatu kelas tanpa merugikan baik secara langsung ataupun tidak terhadap siswa lain atau sekolah. Kedisiplinan belajar sangat penting sesuai dengan pendapat Sari (Anggraini, 2014) bahwa kedisiplinan belajar siswa merupakan salah satu penunjang keberhasilan seseorang dalam memenuhi tugas dan kewajibannya. Oleh sebab itu sangat perlu 
ditanamkan dalam diri siswa sejak dini dan terus-menerus. Kedisiplinan belajar menurut Imron (2011: 172), menyebutkan kedisiplinan dibedakan menjadi 3, yaitu:

1. Kedisiplinan dengan konsep otoritarian, yaitu konsep yang mempunyai kedisiplinan sangat tinggi sehingga siswa harus mengiyakan apa yang dikehendaki guru.

2. Kedisiplinan dengan konsep permissive, yaitu siswa diberi kebebasan yang seluas-luasnya di kelas. Aturan-aturan sekolah dilonggarkan dan tidak perlu mengikat siswa sehingga siswa bebas berbuat apa saja sepanjang hal itu baik.

3. Kedisiplinan belajar yang dibangun berdasarkan konsep kebebasan yang terkendali atau kebabasan yang bertanggung jawab , yaitu kedisiplinan yang memberikan kebebasan seluas-luasnya kepada peserta didik unruk berbuat apa saja, tetapi konsekuensi dari perbuatan itu merupakan tanggung jawab siswa.

Berdasarkan hasil wawancara dan observasi, dapat dilketahui bahwa kedisiplinan siswa di kelas IVa SD Negeri 5 Panjer sebagian siswa sudah memiliki kedisiplinan belajar siswa yang cukup baik, tetapi masih ada sebagian siswa yang lain belum memilikinya. Permasalahan tersebut antara lain: 1) siswa datang terlambat baik saat awal masuk pada pagi hari atau setelah waktu istirahat; 2) tidak memperhatikan saat guru memberikan penjelasan; 3) membuat gaduh; 4) keluar masuk ruang kelas tanpa izin guru; 5) berbicara dengan temannya; 6) sibuk dengan kegiatannya masing-masing; 7) tidak mengumpulkan tugas tepat waktu; 8) tidak membawa buku atau alat sekolah; 9) menganggu temannya saat pembelajaran; 10) membolos.

Peneliti mengumpulkan data yang berkaitan dengan kedisiplinan belajar siswa. Dari kesepuluh pelanggaran di atas peneliti memasukkan ke dalam tiga aspek pelanggaran terhadap kedisiplinan belajar yaitu :

\section{a. Aspek masuk sekolah atau kehadiran siswa.}

Aspek ini meliputi kehadiran siswa (tanpa keterangan/membolos) dan kedatangan siswa di kelas. Berdasarkan hasil wawancara, pada saat pembelajaran Pendidikan Agama Islam pada awal semester dari 22 anak yang berada di kelas IVa ada 1 anak yaitu Di yang tidak mengikuti pembelajaran atau membolos. Guru mengatakan hal ini dikarenakan kenaikan tingkat dari kelas rendah ke kelas tinggi dan siswa belum terbiasa dengan pulang lebih siang. Selain itu, didapati satu siswa yaitu Ro yang sengaja tidak masuk kelas hanya untuk jalan-jalan dan melihat kelas lain. Ketika diajukan pertanyaan, dia menjawab malas masuk kelas. Ini merupakan hal yang memprihatinkan. Menurut guru kelas, Ro memang anak yang memiliki banyak catatan kedisiplinan yang tidak bagus. Dia bersikap semaunya sendiri. Menurut guru, pengaruh dari lingkungan keluarga yang kurang mendukung.

\section{b. Aspek kewajiban siswa salama mengikuti pembelajaran.}

Aspek ini meliputi terlambat masuk kelas, tidak memperhatikan guru saat pembelajaran, membuat gaduh, keluar masuk kelas tanpa izin guru, berbicara dengan temannya, menganggu temannya, dan sibuk dengan kegiatannya sendiri. Pada aspek ini sebagian besar siswa sudah disiplin dalam pembelajaran. Namun, masih ada beberapa siswa yang melanggar peraturan. Siswa masih terlambat dengan alasan yang bervariasi. Selama pembelajaran, anak tidak memperhartikan apa yang disampaikan guru dan berbicara dengan temannya dengan topik pembelajaran di luar yang disampaikan atau memiliki kesibukan yang lain bahkan menganggu temannya Hal ini disebabkan oleh kurangnya minat siswa terhadap bahan yang disampaikan guru dan pembelajaran kurang manarik hati siswa. Pelanggaran lain yang dilakukan 
adalah mereka tidak meminta izin dari guru, baik untuk pergi ke kamar mandi atau mengikuti kegiatan lain di sekolah misalnya mengikuti lomba. Namun, walaupun ditegur salama proses pembelajaran, mereka terus mengulangi kesalahan yang sama.

\section{c. Aspek mengerjakan dan melaksanakan tugas yang diberikan.}

Aspek ini meliputi tidak mengumpulkan tugas tepat waktu dan tidak membawa buku atau alat sekolah yang ditentukan guru. Mengerjakan tugas di kelas maupun di rumah merupakan tanggung jawab siswa sebagai pelajar, maka siswa mandiri dan disiplin. Kondisi di lapangan, ketika guru memberikan tugas kelompok hanya 1-2 anak yang mengerjakan dari 4-5 anak dalam satu kelompok. Selain itu, siswa sering terlambat mengumpulkan tugas bahkan lupa membawa buku atau alat pembelajaran yang telah di tentukan hari sebelumnya. Hal ini dapat terjadi karena anak SD masih kurang fokus dalam menerima suatu hal, maka mereka sering melupakan tugas yang diberikan.

2. Upaya Guru dalam Mengatasi Ketidakdisiplinan Belajar dalam Penanaman Pendidikan Karakter Siswa Kelas IVa SD Negeri 5 Panjer

Guru sebagai pengajar sekaligus pendidik bagi siswa di sekolah. Guru harus memiliki cara dan upaya untuk mengatasi ketidakdisiplinan siswa. Untuk mengatasi ketidakdisiplinan belajar siswa, guru di kelas IVa SD Negeri 5 Panjer melakukan beberapa upaya, yaitu :

a. Mengontrol kelas. Hal ini seperti yang disampaikan oleh Sciara (2010), "To be effective in any teaching situation, a teacher needs to have adequate classroom control. Some would rather call this classroom discipline" yang artinya bahwa kontrol kelas merupakan hal yang penting agar pembelajaran dapat terlaksana dengan efektif, dengan demikian kedisiplinan belajar dapat terlaksana dengan baik.

b. Menegur secara kontinyu sesuai dengan usia dan minat anak. Dengan menegur membuat anak merasa lebih diperhatikan walaupun siswa terus mengulangi kesalahan namun menegur secara terus-menerus akan membuat anak juga merasa terus diperhatikan.

c. Guru selalu memberikan penguatan atau motivasi secara klasikal dengan menggunakan cara yang cukup menarik yaitu bercerita, memberi tugas yang menyenangkan, ataupun memutarkan video.

d. Membuat dan mengingatkan peraturan di kelas secara kontinyu. Ketika digunakan upaya ini selama pembelajaran, anak lebih disiplin dan tertib mengikuti pembelajaran.

e. Pendekatan yang baik. Hal yang utama adalah keteladanan guru dan memberikan teguran kepada siswa secara individu dan memberikan bimbingan klasikal supaya siswa yang lain tidak mengikuti pelanggaran yang dilakukan oleh temannya. Guru berusaha memahami karakteristik siswa kelasnya. Siswa kelas IV cenderung masih terbawa suasana oleh pembelajaran di kelas rendah. Untuk itu, guru tidak terlalu keras dengan siswa. Guru menerapkan kedisiplinan belajar yang dibangun berdasarkan konsep kebebasan yang terkendali atau kebabasan yang bertanggung jawab berdasarkan pendapat Imron (2011) yang artinya siswa mau bertanggung jawab apapun yang terjadi. Sanksi terakhir yang diberikan adalah nilai kosong.

f. Memberikan kesempatan kepada siswa untuk berusaha mencari penggantinya saat itu juga.

g. Memberikan sanksi yang mendidik kepada siswa. Salah satu contohnya adalah menyanyi lagu kebangsaan atau lagu daerah bagi yang terlambat ataupun mengerjakan tugas di depan kelas. Upaya ini dilakukan guru selain untuk 
mendisiplinkan siswa juga upaya untuk melatih keberanian dan keterampilan siswa dalam menghafal lagu-lagu kebangsaana ataupun lagu daerah.

\section{SIMPULAN}

Dari penelitian yang dilakukan maka dapat disimpulkan:

1. Kedisiplinan belajar dalam penanaman pendidikan karakter siswa kelas IVa SD Negeri 5 Panjer masih kurang, hal ini dapat dilihat dari pelanggaran, yaitu : 1) siswa datang terlambat baik saat awal masuk pada pagi hari atau setelah waktu istirahat; 2) tidak memperhatikan saat guru memberikan penjelasan; 3) membuat gaduh; 4) keluar masuk ruang kelas tanpa izin guru; 5) berbicara dengan temannya; 6) sibuk dengan kegiatannya masing-masing; 7) tidak mengumpulkan tugas tepat waktu; 8) tidak membawa buku atau alat sekolah; 9) menganggu temannya saat pembelajaran; 10) membolos. Hal tersebut disebabkan oleh beberapa hal yaitu kurangnya minat siswa dalam belajar, siswa tidak fokus dan mudah lupa, dan siswa masih terbawa suasana pembelajaran kelas rendah.

2. Upaya yang dilakukan guru yaitu memberi teguran dan nasihat, memberikan sanksi, melakukan pendekatan dan memahami karakteristik setiap anak karena guru kelas yang paling sering berhadapan dengan siswa, memberikan teguran dan nasihat secara terus menerus, dan memberikan motivasi setiap pembelajaran baik di awal, tengah, maupun akhir.

\section{DAFTAR PUSTAKA}

Anggraini, A.J. (2014). Kedisiplinan Belajar Siswa Kelas V SD Negeri 1 Parangtritis: Studi Kasus. Skripsi. Unversitas Negeri Yogyakarta.

Imron, A. (2011). Manajemen Peserta Didik Berbasis Sekolah. Jakarta: Bumi Aksara. Sangadji, E.M. dan Sopiah. (2010). Metodologi Penelitian. Yogyakarta: Penerbit Andi.

Sciara, F. J. (2010. Effective Classroom Discipline: A Proposal for Maximing Student Teacher Learning. The Teacher Educator, 6(2), 21-26.

Suyono dan Hariyanto. (2014). Belajar dan Pembelajaran Teori dan Konsep Dasar. Bandung: PT. Remaja Rosdakarya. 